\title{
AS FACULDADES MUNICIPAIS DE SÃO PAULO: ASPECTOS DE SUA ORIGEM E ORGANIZAÇÃO ACADÊMICO-INSTITUCIONAL (1960-1975)
}

Silvana Aparecida Bretas ${ }^{1}$

\section{RESUMO}

Este artigo insere-se no campo da História da Educação, tendo como objeto de estudo as faculdades municipais do estado de São Paulo. O objetivo é apresentar aspectos de suas origens e de suas organizações acadêmicas correspondentes ao estatuto científico da área de sua abrangência. Das quase 40 faculdades municipais paulistas foram selecionadas a Faculdade de Ciências Econômicas, Administrativas e Contábeis de Franca, a Faculdade de Filosofia, Ciências e Letras de São José do Rio Pardo e a Escola de Engenharia de Piracicaba. Em cada uma, cercou-se da pesquisa documental, especialmente, as referentes à suas origens e à dinâmica acadêmico-institucional. Nas considerações finais procurou traçar uma comparação desses aspectos e apontar algumas perspectivas acadêmicas que se delineiam para um futuro próximo destas IMES.

Palavras-chave: faculdades municipais; ensino superior; ciência; educação.

\section{MUNICIPAL COLLEGES OF SAO PAULO: ASPECTS OF THEIR ORIGIN AND ORGANIZATION-ACADEMIC INSTITUTION}

\begin{abstract}
This article belongs to the field of history of education, aiming to study the municipal colleges in the State of São Paulo. The goal is to present aspects of their origins and their organizations corresponding to the academic scientific status of their coverage area. Of the nearly 40 colleges were selected municipal Sao Paulo School of Economics, Administration and Accounting from Franca, the Faculty of Philosophy, Sciences and Literature of Sao Jose do Rio Pardo and the Engineering School of Piracicaba. The article presented a documentary research, especially regarding its origins and academicinstitutional dynamics. In conclusion there is a comparison of these aspects and point out some academic perspectives which delineate for the near future these IMES.
\end{abstract}

Keywords: municipal colleges, higher education, science and education.

As formas e os processos educativos constituem, do ponto de vista histórico, uma dimensão social que se define como práticas integradas ao processo cultural amplo. A educação formal é parte dessa dimensão que se desenvolve através de uma ação deliberada que, a partir da era moderna, está organizada pelo Estado e acomodada em instituições públicas e privadas, de caráter laico ou confessional. As relações entre a educação como prática social e a educação formal compõem, conforme a perspectiva de análise, o objeto de estudo da História da Educação.

Para Warde (1990, p. 8.) e Caspard (1990, p. 8) a História da Educação deve inscrever-se fortemente na História, não se restringindo aos fatores que desenham os contextos da evolução dos fenômenos educativos. Para, além disso, deve fazer emergir a natureza de seu objeto de estudo em função das interrogações e das exigências próprias dos 
problemas de pesquisa. Nessa perspectiva, o presente artigo insere-se no campo de análise da História da Educação, tendo como objeto de estudo as faculdades municipais do estado de São Paulo que tiveram suas origens nos meados dos anos de 1950, demarcando sua expansão nos anos de 1960 a 1975. O objetivo principal é apresentar alguns aspectos de suas respectivas constituições históricas bem como, demonstrar suas organizações acadêmicas correspondente ao estatuto científico da área de sua abrangência.

Essas faculdades, tomadas quase sempre de forma difusa, raras vezes chamaram a atenção dos pesquisadores para seus reais problemas, já que sua existência e expansão sempre foram explicadas na ampla categoria de instituições privadas obscurecendo, assim, uma compreensão mais plausível de sua organização e do domínio do público e do privado na dependência administrativa municipal.

A participação de municípios na oferta de ensino superior, no Brasil, data dos meados da década de 1950. A legislação que vigorou no período e, posteriormente, o Decreto-Lei $\mathrm{n}^{\circ}$. 200/67 permitiram que as entidades da administração indireta ${ }^{2}$, por possuírem personalidade jurídica pública, ofertassem serviços públicos. Assim, o poder municipal, através de suas autarquias e, mais tarde, de suas fundações, teve a chance de expandir-se nesse nível de ensino.

Por institutos municipais de ensino superior, neste trabalho, entendem-se...

[...] todas as entidades subordinadas ao Conselho Estadual de Educação, constituídas sob a forma de autarquias municipais, fundações públicas ou privadas municipais [...] O critério para que a instituição possa pertencer ao Sistema Estadual de Ensino Superior, ainda segundo o CEE, é o fato de ter sido criada por uma lei municipal ou estadual (MACHADO NETO, 2000, p. 89).

O estado que deu origem a este setor do ensino superior foi o de São Paulo, nos meados dos anos de 1950, com a criação de duas faculdades, seguidas por outras, em diferentes municípios, ao longo das décadas de 1960 e 1970, conforme se observa no quadro abaixo:

Quadro 1 - Institutos de ensino superior de São Paulo

\begin{tabular}{|c|c|c|}
\hline FACULDADE & MUNICÍPIO & ATO LEGISLATIVO \\
\hline $\begin{array}{l}\text { Faculdade de Ciências Econômicas e } \\
\text { Administrativas e Contábeis }\end{array}$ & Santo André & Decreto Federal. n $35.540 / 54$ \\
\hline Faculdade de Direito & Franca & Lei Municipal n 653/57 \\
\hline Faculdade de Administração e Economia & $\begin{array}{l}\text { São João da } \\
\text { Boa Vista }\end{array}$ & Lei Municipal n 187/61 \\
\hline $\begin{array}{l}\text { Faculdade de Ciências Econômicas e } \\
\text { Administrativas e Contábeis }\end{array}$ & Franca & Lei Municipal. $n^{\circ} 1.143 / 63$ \\
\hline $\begin{array}{l}\text { Faculdade de Ciências Econômicas e } \\
\text { Administrativas }\end{array}$ & Osasco & Lei Municipal n 403/64 \\
\hline Faculdade de Filosofia, Ciências e Letras & $\begin{array}{l}\text { São José do Rio } \\
\text { Pardo }\end{array}$ & Lei Municipal. n 415/64 \\
\hline Faculdade de Engenharia & Barretos & $\begin{array}{l}\text { Parecer do Conselho Federal de } \\
\text { Educação. n }{ }^{\circ} 57 / 66\end{array}$ \\
\hline Faculdade de Filosofia, Ciências e Letras & Catanduva & Lei Municipal. $n^{\circ} 803 / 66$ \\
\hline Faculdade de Filosofia, Ciências e Letras & Penápolis & Lei Municipal n 490/66 \\
\hline
\end{tabular}




\begin{tabular}{|c|c|c|}
\hline FACULDADE & MUNICÍPIO & ATO LEGISLATIVO \\
\hline Faculdade de Filosofia, Ciências e Letras & Santo André & Decreto Federal. n’ 57.849/66 \\
\hline Faculdade de Filosofia, Ciências e Letras & Adamantina & Lei Municipal. n 853/67 \\
\hline Faculdade de Filosofia, Ciências e Letras & $\begin{array}{l}\text { Bragança } \\
\text { Paulista }\end{array}$ & Lei Municipal. $n^{\circ} 855 / 67$ \\
\hline Escola de Engenharia & Piracicaba & Lei Municipal. $\mathrm{n}^{\circ} 1.556 / 68$ \\
\hline Instituto de Ensino Superior & $\begin{array}{l}\text { São Caetano do } \\
\text { Sul }\end{array}$ & $\begin{array}{l}\text { Resolução do Conselho Estadual de } \\
\text { Educação } n^{\circ} 16 / 68\end{array}$ \\
\hline Faculdade de Medicina & Jundiaí & $\begin{array}{l}\text { Resolução do Conselho Estadual de } \\
\text { Educação. n⿳ 6/69 }\end{array}$ \\
\hline Faculdade de Medicina & Santo André & Decreto Federal. n 64.062/69 \\
\hline Faculdade de Ciências e Letras & Avaré & $\begin{array}{l}\text { Parecer Conselho Estadual de Educação } \\
n^{\circ} 224 / 69\end{array}$ \\
\hline Faculdade de Ciências & Barretos & $\begin{array}{l}\text { Resolução do Conselho Estadual de } \\
\text { Educação n } 3 / 69\end{array}$ \\
\hline Escola Superior de Educação Física & Cruzeiro & Lei Municipal. $\mathrm{n}^{\circ}$ 1.007/69 \\
\hline Faculdade de Engenharia Química & Lorena & Lei Municipal. n 687/69 \\
\hline Escola Superior de Educação Física & Avaré & $\begin{array}{l}\text { Parecer do Conselho Estadual de } \\
\text { Educação } n^{\circ} 135 / 72\end{array}$ \\
\hline Faculdade de Filosofia, Ciências e Letras & Jaú & $\begin{array}{l}\text { Parecer do Conselho Estadual de } \\
\text { Educação n }{ }^{\circ} 680 / 72\end{array}$ \\
\hline Faculdade de Educação Física & Santa Fé do Sul & $\begin{array}{l}\text { Parecer do Conselho Estadual de } \\
\text { Educação } n^{\circ} 158 / 72\end{array}$ \\
\hline Instituto de Ensino Superior & Mococa & Decreto Federal n ${ }^{\circ} 71.305 / 72$ \\
\hline Instituo Municipal de Ensino Superior & São Manuel & Decreto Federal n ${ }^{\circ} 71.609 / 72$ \\
\hline Escola Superior de Educação Física & Jundiaí & $\begin{array}{l}\text { Parecer do Conselho Estadual de } \\
\text { Educação n } 2.992 / 73\end{array}$ \\
\hline Universidade Municipal & Taubaté & Lei Municipal n $1.498 / 74$ \\
\hline
\end{tabular}

Fonte: Dias, $1989^{3}$.

Estudos realizados pelo Conselho Estadual de Educação de São Paulo (SÃO PAULO, 1995) ratificam e complementam os dados apresentados no quadro acima. Verifica-se que foram instaladas, entre 1960 e 1975, mais de duas dezenas desses estabelecimentos, abrangendo diversas áreas do conhecimento, com prevalência para os cursos da área de Ciências Humanas, em especial os de Pedagogia, Letras e Estudos Sociais. Segundo levantamento da Assistência Técnica do CEE-SP, somente nos anos de 1960 a 1975, surgiram 27 IMES, sendo 17 na área de Ciências Humanas, dois na de Medicina, três na de Engenharia, quatro na de Educação Física e uma universidade. A distribuição geográfica ocorreu de forma equilibrada, atingindo várias regiões do estado: da região metropolitana da cidade de São Paulo até municípios muito distantes dela (SÃO PAUO, 1995, p. 11).

Em 1993, estavam sob a jurisdição do CEE-SP 41 institutos municipais de ensino superior, localizados em 28 municípios4. Dados mais recentes apresentam um quadro com 12 faculdades de Filosofia, Ciências (e Letras), sete IMES, quatro faculdades de Ciências Econômicas (Contábeis e Administração), quatro escolas superiores de Educação Física, 
quatro faculdades de Direito, duas faculdades de Enfermagem e Obstetrícia, duas faculdades de Medicina, duas faculdades de Odontologia, três faculdades de Tecnologia, duas federações de escolas de ensino superior e uma universidade. Oferecem, anualmente, um total de 14.681 vagas, abrigando 32.489 alunos.

Desde a criação dos IMES até o início da década de 1990, a incidência maior de matrículas foi nos cursos de licenciatura e nos cursos de bacharelado que profissionalizam para o setor terciário, conforme demonstrado na primeira publicação da Série Estudos e Normas, sob o título de Ensino Superior Municipal no Estado de São Paulo. Das 31.116 matrículas efetivadas em 1993, 13.251 são em cursos de licenciatura, 13.004 em cursos de bacharelados para o setor de serviços, 3.324 em cursos da área de saúde e apenas $1.537 \mathrm{em}$ cursos do setor de tecnologia (op.cit., p. 22-24).

Tentando definir uma periodização dos IMES, é possível reconhecer os momentos de sua expansão e seu desenvolvimento nas décadas de 1960 e 1970, período em que, possivelmente, se vislumbram as singularidades do objeto de estudo5.

Para efetivar a escolha dos institutos que seriam estudados, foi estabelecida uma matriz referencial, considerando-se, como critérios, as seguintes categorias: temporal (data da fundação), disciplinar (tipos de cursos que ministram), administrativa (autarquia ou fundação), dos docentes (titulação), dos discentes (matrículas anuais, ingressantes e egressos) e a espacial (distribuição geográfica).

No cruzamento matricial, foi possível escolher quatro instituições municipais de ensino superior. São elas: "Faculdade de Filosofia, Ciências e Letras de São José do Rio Pardo", "Escola de Engenharia de Piracicaba", "Faculdade de Ciências Econômicas e Administrativas e Contábeis de Franca", "Faculdade de Filosofia, Ciências e Letras" de Santo André. No desenvolvimento da pesquisa de campo não nos foi possível investigar a documentação dessa última Faculdade, visto que o conjunto de documentos encontrava-se no teto do prédio da biblioteca sem tratamento arquivístico, impossibilitando a coleta de informações. Neste caso, decidiu-se por investigar apenas as outras três Faculdades referidas acima.

\subsection{A Faculdade de Filosofia, Ciências e Letras de São José do Rio Pardo}

Em estudo especial publicado na Revista Documenta (BRASIL, 1968, p. 3-9), o então Conselheiro Anísio Teixeira analisa o Artigo 15, da Lei no 4.024, de 20 de dezembro de 1961, das Diretrizes e Bases da Educação Nacional, que definia a competência do Conselho Federal de Educação (CFE). Para o educador, esse dispositivo, considerando-se a forma original do parágrafo $2^{\circ}$, do artigo $9^{\circ}$, era causa de uma dualidade jurisprudencial. Isso, porque o artigo definia como competência do CFE "decidir sobre o funcionamento dos estabelecimentos isolados de Ensino Superior", enquanto o parágrafo estabelecia que "a autorização e fiscalização dos estabelecimentos estaduais isolados de Ensino Superior caberão aos Conselhos Estaduais de Educação na forma da lei estadual respectiva". Completando: "Só se transfere essa autorização para o estado quando este mantém uma universidade própria há mais de cinco anos". No caso do CEE-SP, que decidia a sobre a Universidade de São Paulo havia mais de trinta anos, Anísio Teixeira não vislumbrava qualquer vantagem em manter a dualidade de jurisdição (federal e estadual), pois isso tinha consequências práticas na autorização e no reconhecimento do ensino superior. Assim ele prossegue em seu exame:

Parece haver isto criado a preferência para caracterizar as próprias 
instituições mantidas pelo poder público - geralmente municipal - como instituições privadas, a fim de caírem sob a jurisdição federal. Há repetidos casos em São Paulo [...] em que governos municipais vêm criando escolas que procuram caracterizar como particulares mediante o artifício da fundação, que julgam poder ser privadas, a fim de escaparem da jurisdição estadual (TEIXEIRA, 1968, p.11).

$\mathrm{O}$ alerta do conselheiro chama o CEE-SP à responsabilidade de regulamentar as faculdades municipais paulistas. Vê-se, então que no período delimitado para o estudo, vislumbra-se o seguinte quadro por categoria administrativa:

Quadro 2 - Dependência Administrativa das Faculdades Municipais de São Paulo

\begin{tabular}{|c|c|c|}
\hline FACULDADE & MUNICÍPIO & $\begin{array}{l}\text { CLASSIFICAÇÃO } \\
\text { ADMINISTRATIVA }\end{array}$ \\
\hline $\begin{array}{l}\text { Faculdade de Ciências Econômicas e } \\
\text { Administrativas e Contábeis }\end{array}$ & Santo André & Fundação Educacional \\
\hline Faculdade de Direito & Franca & Autarquia Municipal \\
\hline Faculdade de Administração e Economia & $\begin{array}{l}\text { São João da Boa } \\
\text { Vista }\end{array}$ & Autarquia Municipal \\
\hline $\begin{array}{l}\text { Faculdade de Ciências Econômicas e } \\
\text { Administrativas e Contábeis }\end{array}$ & Franca & Autarquia Municipal \\
\hline Faculdade de Filosofia, Ciências e Letras & $\begin{array}{l}\text { São José do Rio } \\
\text { Pardo }\end{array}$ & Autarquia Municipal \\
\hline $\begin{array}{l}\text { Faculdade de Ciências Econômicas e } \\
\text { Administrativas }\end{array}$ & Osasco & $\begin{array}{l}\text { Fundação do Instituto } \\
\text { Tecnológico de Osasco }\end{array}$ \\
\hline Faculdade de Engenharia & Barretos & Fundação Educacional \\
\hline Faculdade de Filosofia, Ciências e Letras & Catanduva & Autarquia Municipal \\
\hline Faculdade de Filosofia, Ciências e Letras & Penápolis & Fundação Educacional \\
\hline Faculdade de Filosofia, Ciências e Letras & Santo André & Fundação Educacional \\
\hline Faculdade de Filosofia, Ciências e Letras & Adamantina & Autarquia Municipal \\
\hline Faculdade de Filosofia, Ciências e Letras & Bragança Paulista & Fundação Educacional \\
\hline Escola de Engenharia & Piracicaba & Fundação Educacional \\
\hline Instituto de Ensino Superior & São Caetano do Sul & Autarquia Municipal \\
\hline Faculdade de Medicina & Jundiaí & Autarquia Municipal \\
\hline Faculdade de Medicina & Santo André & Fundação Educacional \\
\hline Faculdade de Ciências e Letras & Avaré & Fundação Educacional \\
\hline Faculdade de Ciências & Barretos & Fundação Educacional \\
\hline Escola Superior de Educação Física & Cruzeiro & Autarquia Municipal \\
\hline Faculdade de Engenharia Química & Lorena & $\begin{array}{l}\text { Autarquia Estadual de Regime } \\
\text { Especial }\end{array}$ \\
\hline Escola Superior de Educação Física & Avaré & Fundação Educacional \\
\hline Faculdade de Filosofia, Ciências e Letras & Jaú & Fundação Educacional \\
\hline Faculdade de Educação Física & Santa Fé do Sul & Fundação Educacional \\
\hline
\end{tabular}




\begin{tabular}{|l|l|l|}
\hline \multicolumn{1}{|c|}{ FACULDADE } & \multicolumn{1}{|c|}{ MUNICÍPIO } & \multicolumn{1}{c|}{$\begin{array}{c}\text { CLASSIFICAÇÃO } \\
\text { ADMINISTRATIVA }\end{array}$} \\
\hline $\begin{array}{l}\text { Faculdade de Ciências Econômicas e } \\
\text { Administrativas e Contábeis }\end{array}$ & Santo André & Fundação Educacional \\
\hline Faculdade de Direito & Franca & Autarquia Municipal \\
\hline Faculdade de Administração e Economia & $\begin{array}{l}\text { São João da Boa } \\
\text { Vista }\end{array}$ & Autarquia Municipal \\
\hline $\begin{array}{l}\text { Faculdade de Ciências Econômicas e } \\
\text { Administrativas e Contábeis }\end{array}$ & Franca & Autarquia Municipal \\
\hline Instituto de Ensino Superior & Mococa & Fundação Educacional \\
\hline Instituo Municipal de Ensino Superior & São Manuel & Autarquia Municipal \\
\hline Escola Superior de Educação Física & Jundiaí & Autarquia Municipal \\
\hline Universidade Municipal & Taubaté & Autarquia Municipal \\
\hline
\end{tabular}

Fonte - CEESP - SP, 2003.

A preocupação de Anísio Teixeira se confirma, pois se criaram mais fundações do que autarquias e, nesse caso, há um complicador, porque o estatuto que então regulamentava a administração indireta, o Decreto-Lei 200/67, não considerava as fundações. Esse dado corrobora a tese de Dourado, a de que a iniciativa privada usava o poder municipal para viabilizar a autorização e funcionamento de suas instituições de ensino superior. Não se equivoca o autor ao afirmar que o melhor modo de definir as faculdades municipais é identificá-las como entidades públicas não-gratuitas. Convém recordar que a LDB de 1961 permitia que as escolas públicas se organizassem sob a forma de fundação. No parecer de aprovação da faculdade de Barretos, São Paulo, destaca-se o seguinte trecho:

A organização escolar do tipo de fundação não retira o caráter público da escola. Seu método de administração é que se aproxima das organizações privadas, mas sua função é pública, seus interesses são públicos, sua responsabilidade é pública (REVISTA DOCUMENTA, 1968, p. 19).

A assertiva demonstra que a constituição histórica de cada uma delas trilha caminhos que permitem o debate sobre seu caráter público ou privado, oferecendo elementos que vão além das questões jurídicas. A Faculdade de Filosofia, Ciência e Letras de São José do Rio Pardo, por exemplo, guarda singularidades de sua origem e de sua organização inicial, confrontáveis com as questões colocadas acima.

O início de suas atividades se deu no mês de fevereiro de 1966, quando o então diretor, Padre Glauco do Prado Nogueira, assume sua administração. Criada pela Lei Municipal $\mathrm{n}^{\circ}$ 415, de 27 de abril de 1964, como entidade autárquica de regime jurídico único (estatutário), foi autorizada a funcionar pela Resolução $n^{\circ}$ 23/66, do CEE-SP, e pelo Decreto Estadual $n^{\circ} 46.243$, de 6 de maio de 1966. Ela foi reconhecida pelo Parecer $n^{\circ}$ 353/70, também do CEE-SP, e pelo Decreto Federal n 68.308 de 2 de março de 1971, como personalidade jurídica própria e de direito público, com sede e foro no município de São José do Rio Pardo.

$\mathrm{Na}$ referida lei municipal, em seu artigo $3^{\circ}$, é criado o conselho deliberativo da faculdade, composto pelo juiz de direito e pelo promotor público da comarca, por um representante da Câmara de Vereadores e outro do executivo municipal, pelo diretor do 
Instituto Euclides da Cunha e quatro professores indicados pela congregação desse instituto. A presença de representantes da sociedade no conselho foi proposta que partiu dessa congregação, que, desde os idos de 1950, aspirava fazer da cidade de São José de Rio Pardo o maior centro de ensino da Média Mogiana (GUERRA, 1996).

Já em 1956, o então governador Jânio Quadros resolveu descentralizar o ensino superior em São Paulo e, para isso, enviou técnicos em educação para observar os municípios, no que toca seus aspectos estruturais, geográficos e culturais. Assim, logo se organizou uma comissão pró-criação da "Faculdade Municipal de Filosofia Euclides da Cunha"6. Esse é um dado muito importante, pois seus idealizadores tinham clara a organicidade dessa escola com a própria cidade e, sobretudo, desejavam uma faculdade na área das Humanidades, de formação intelectual e acadêmica. Isso se deu, provavelmente, pelo culto à imagem do autor de "Os Sertões", uma tradição cultural que a cidade se incumbe de preservar.

Desde 1912, São José do Rio Pardo é a Meca do euclidianismo, dedicando-se o mês de agosto a sua vida e obra, quando se promove a Semana Euclidiana, pelo fato de seu livro mais importante ter sido concluído nessa cidade. Médicos, advogados, engenheiros, estudantes, políticos, intelectuais em geral, enfim, toda a população cultua a memória de Euclides da Cunha, preservando sua residência, hoje Casa de Cultura Euclidiana, até mesmo a cabana de zinco, que ele utilizou durante a construção da ponte sobre o Rio Pardo, hoje protegida por uma redoma de vidro.

Foi nesse clima cultural, entre as idas e vindas do trâmite político-institucional, que o governador Jânio Quadros, em 1957, pediu à reitoria da USP estudos urgentes para a criação da Faculdade de Filosofia de São José do Rio Pardo. Recebendo apoio de prefeitos da Média Mogiana, o então prefeito rio-pardense, Lupércio Torres, assina um documento que solicita ao governador a instalação da almejada faculdade.

Em determinada altura dos acontecimentos, os que se organizavam para a criação da faculdade cogitaram uma escola de ensino superior de Farmácia e Odontologia. Porém, chegando a São Paulo, foram dissuadidos pelo médico, professor da USP, diretor da Faculdade de Odontologia de Piracicaba e membro do CEE-SP, Carlos Henrique Robertson Liberalli, a abandonar essa ideia e optar por Humanidades, dada a facilidade de recrutar professores. Como dizia Mendes (1968, p. 33-37), entre os desperdícios mais funestos da nossa política de ensino superior, coloca-se a criação de cursos "fáceis", tais como Ciências Econômicas, Direito e Serviço Social e os de formação de professores que possibilitam a expansão deste setor de ensino através áreas de baixo custo financeiro e de fácil recrutamento de professores.

Em 27 de abril de 1964, a Câmara Municipal aprova o projeto que cria a Faculdade de Filosofia, Ciências e Letras de São José do Rio Pardo. O poder público municipal foi fundamental para sua instalação: assumiu o aluguel do prédio, de propriedade da Congregação das Filhas de Nossa Senhora do Monte Calvário; o acervo da biblioteca municipal foi transferido para a escola de ensino superior que surgia; um convênio firmado com o Instituto Euclides da Cunha permitia que os alunos universitários frequentassem sua biblioteca. Por outro lado, permitiu-se ao prefeito a utilização dos excedentes de arrecadação, dos saldos de verbas não utilizadas e o gerenciamento das dotações federais, estaduais, municipais e de particulares, a fim de garantir o funcionamento da recém-criada faculdade (SÃO JOSÉ DO RIO PARDO, 1964).

Os cursos iniciais eram os de Letras, Pedagogia, Ciências Sociais e História, o que reflete uma das características da expansão do ensino superior daquele período. Além do mais, a formação de professores do ensino fundamental e do médio era considerada estratégica para o desenvolvimento do país (REVISTA DOCUMENTA, 1968, p. 12). 
Os que se dedicavam à instalação da faculdade mantinham a população informada através da imprensa local. Assim que seu funcionamento foi aprovado, a população foi convocada a comemorar, na Praça XV de Novembro, a conquista. Foi através da imprensa que se divulgou o primeiro concurso vestibular, o número de vagas em cada curso e de inscritos, bem como as cidades de origem dos candidatos. As informações ganhavam um caráter qualitativo e, mesmo, ufanista, à medida que se discutia a razão da faculdade. No final de maio de 1964, o professor Hersílio Ângelo faz a seguinte reflexão:

Evitemos um corpo docente de fachada (medalhões) [...] Que se evite uma escola normal rotulada de faculdade de filosofia. A Faculdade de Filosofia é a cúpula da Universidade; é o coroamento de todas as faculdades, pelo aperfeiçoamento do ensino, pela universalidade da cultura nacional. Se não compreendermos bem esses pontos, vamos, apenas, concorrer para a proliferação da má escola, o que é contrário de uma Faculdade de Filosofia. Esse mal parece vir de longe (REVISTA LOGO, 1969).

Acompanhando os estudos de Vaidergorn (1995, p. 75), sobre a origem e a concepção de muitas das faculdades de Filosofia brasileiras, segundo o modelo germânico e o francês, constata-se:

Só em 1934, com a fundação da USP, surgiu a primeira Faculdade de Filosofia, Ciências e Letras nos moldes da pesquisa pura e da 'cultura desinteressada' conforme o disposto no Manifesto [dos Pioneiros], modeladora de uma elite intelectual e da formação de docentes para o ensino básico e médio, e que realizaria a concepção universitária sustentadas pelos seus criadores.

Considerando-se a fala de Hersílio Ângelo, não seria um exercício de pura abstração afirmar que a Faculdade de Filosofia, Ciências e Letras de São José do Rio Pardo buscou suas bases no modelo que inspirou a fase inicial da USP. Os princípios que levaram o professor Hersílio Ângelo a defender a faculdade foram frutos de uma escolha consciente, que percorrerá os anos sequentes, sem que os membros do CEE-SP e próprios professores se dessem conta disso. É o que se demonstrará mais adiante.

Por ora, convém considerar o debate que se tratava no âmbito do CFE, sobre a função social de uma Faculdade de Filosofia, Ciências e Letras (FFCL). Como demonstrou Vaidergorn (op. cit., p.17 -102), as bases da universidade repousavam no conhecimento fundamental gerido por uma faculdade de Filosofia. Ela seria o elemento integrador de todas as faculdades. Essa configuração fundamentou o Decreto $\mathrm{n}^{\circ} 19.851$, de 11 de abril de 1931, hoje revogado, que dispunha sobre o ensino superior e instituía um estatuto para as universidades brasileiras.

Segundo ele, definia-se o reconhecimento de universidade a partir da existência de, no mínimo, cinco estabelecimentos de ensino científico, introduzindo-se a figura da administração comum. Foi vetada a antiga função da FFCL como órgão integrador de todos os conhecimentos. Caberia, efetivamente, a cada estabelecimento, a substância de universalidade reunida sob a forma acadêmica de organização (REVISTA DOCUMENTA, 1968, n. 81, p. 145).

Essa nova configuração gerou a possibilidade de criar FFCL como instituto isolado. A declaração de voto do Conselheiro Miguel Reale, em maio de 1968, expõe contundentes críticas ao antigo papel desse tipo de faculdade. Para ele, o próprio plano em que se desejava a integração não resultou em ação prática, porque era fruto de um "intelectualismo abstrato e insusceptível de vingar. Como não vingou, até mesmo nas 
Universidades instituídas [...]" (op. cit., p. 192). Mais adiante, continua o conselheiro: "As FFCL devem adequar-se à nova lei, como escolas de formação profissional e pesquisa aplicada" 7. Miguel Reale compreendia as transformações do conhecimento científico e pretendia convencer seus pares sobre como se traduziam tais transformações para as FFCL, ou seja, como elas poderiam instrumentalizar as Ciências Humanas.

Para que houvesse cursos autônomos nessas faculdades, seria necessário substituir suas antigas estruturas, de "modelo abstrato e cerebrino de escola polivalente", dada as desproporções de recursos técnicos, financeiros e culturais, dos diferentes estados e municípios brasileiros, atendendo às novas exigências de profissionalização e pesquisa aplicada, tal como já foi exposto. Assim finaliza sua declaração de voto:

A incongruência de tais situações foi se tornando cada vez mais insuportável à medida que veio se expandindo e descentralizando a rede de Ensino Superior, passando os municípios a desempenhar um papel relevante nessa ordem de atividades, ou foram surgindo entidades privadas empenhadas em ministrar formação universitária às populações interioranas (REVISTA DOCUMENTA, 1968, n. 81, p. 148).

A expansão e a interiorização do ensino superior exigiram novas organizações institucionais, não se alterando, contudo, as concepções daqueles que pleiteavam esse nível de ensino para suas cidades. As bases da FFCL de São José do Rio Pardo, prenunciadas por Hersílio Ângelo, possuíam fundamentos advindos da própria formação desse professor e de suas atividades intelectuais. Por isso, é possível afirmar que a condição de estabelecimento integrador dos conhecimentos universais era um princípio norteador da FFCL, muito embora a Faculdade não fosse capaz de atendê-lo, uma vez que era um estabelecimento isolado. No entanto, volta-se a repetir, como instituição de Ciências Humanas, a FFCL de São José do Rio Pardo apresentou o ethos científico próprio, em termos de ensino superior.

Uma questão por ora se coloca: Por que não progrediu a pesquisa nessa instituição? Considerando-se as atividades de outros docentes, percebe-se a existência de um grupo de intelectuais com produção acadêmica significativa e, no entanto, não reconhecida nem pelos próprios diretores e, muito menos, pelo CEE-SP. Por que razão? Em resposta ao Processo $\mathrm{n}^{\circ}$. 715/69, tramitado nesse conselho, que relatava as atividades acadêmicas da faculdade, o diretor, Padre Glauco do Prado Nogueira, afirma:

Pelo fato de estar a faculdade ainda no seu terceiro ano de vida, não houve, em 1968, programações e realizações no campo das pesquisas, que ficaram circunscritas a algumas disciplinas de determinados cursos. [...] Ainda pelas razões apontadas na letra 'a', supra, não houve, em 1968, planos para a organização da pesquisa8.

Esses argumentos se repetem nos relatórios de 1969 e 19709, não se reconhecendo as atividades dos professores, mesmo as da iniciativa individual, como de pesquisa. Desse mesmo modo procede o CEE-SP.

Há um caso muito elucidativo, que demonstra a posição do CEE-SP, em relação às atividades de pesquisa nas faculdades municipais. Trata-se do prontuário do professor Geraldo Majela Furlani, licenciado em História e Geografia pela FFCL da Universidade Católica de Campinas, pós-graduado em Geografia pela USP, em 1969, tendo freqüentado o curso de Sedimentologia, do Instituto de Geografia da USP. Cursou, ainda, outro aperfeiçoamento em Geografia, na Universidade Católica de Campinas, e mestrou-se na 
mesma área, na Universidade de São Paulo, em 1981. Suas publicações são as seguintes: "As boçorocas de Casa Branca e seu significado geomorfológico" (BOLETIM DE GEOMORFOLOGIA, São Paulo, n. 10, 1960 - USP), “A geografia de 'Os sertões' Análise da Terra"10 e "Euclídes - Terra e homem"11.

Vê-se que a produção intelectual do professor não é nada modesta, apesar da inexistência de incentivo para a atividade de pesquisa. A propósito, ao Ofício $n^{\circ}$ 123/70, encaminhado pela FFCL de São José do Rio Pardo ao CEE-SP, pedindo autorização para o professor Majela assumir as cadeiras de História da Geografia e Geografia do Brasil, o presidente do conselho, professor Paulo Ernesto Tolle, respondeu com as seguintes ponderações:

\begin{abstract}
Ainda aqui desejo que fique preliminarmente explicito [sic] meu modo pessoal de encarar o problema do professorado destinado às faculdades municipais: a) destina-se à formação de profissionais (no caso de professores de grau médio) e não ao desenvolvimento da pesquisa científica $^{12}$; a pesquisa que faz ou fará é atividade complementar e indispensável da docência superior, mas se não pode lhe exigir características muito avançadas, em função da sua própria finalidade e da escassez de pessoal qualificado, de alto nível; [sic] b) irá receber dos cofres municipais retribuição bem mais escassa que o professorado dos cursos superiores oficiais (estaduais e federais), o que faz com que boa parte de sua tarefa possa ser olhada, sem exagêro [sic] como contribuição quase desinteressada ao desenvolvimento cultural da comunidade; c) esse professorado deverá satisfazer, por conseguinte, aos padrões mínimos, mas tão somente a eles. Não será a posse do título de grau superior em currículo que contenha as disciplinas que se propõe a lecionar, suplementando por cursos de aperfeiçoamento, concursos, exercícios de funções docentes correlatas e trabalhos publicados, credenciais estas que, se vultosas, poderão suprir a ausência daquele primeiro requesito [sic]. Outro não é, aliás, o entendimento desta Câmara e do Egrégio Conselho Pleno, quando fixou as normas para a autorização de escolas superiores, mantidas pelo estado ou pelos municípios, nem diverso é o entendimento que da matéria tem o Conselho Federal de Educação. Restringe-se tudo a uma maneira quantitativa de apreciar os títulos: mais exigentemente [sic] para os candidatos do magistério superior mantido pelo Estado, menos e exigentemente [sic] para os outros. O Estado é equânime que se estenda idêntica bitola ao professorado, geralmente idealista e abnegado, que se dispõe a ensinar nas faculdades municipais ${ }^{13}$.
\end{abstract}

A ação deliberada do Estado tornou um fato a fragmentação da estrutura institucional que se foi configurando após a reforma universitária de 1968. Em outras palavras, criaram-se e consolidaram-se dois patamares de instituições de ensino superior: um voltado à indissociabilidade entre ensino, pesquisa e extensão, tal como preconiza a Lei $\mathrm{n}^{\mathrm{o}} 5.540$, de 28 de novembro de 196814, e outro somente ao ensino como coisa menor, de menos importância, sem necessidade de pesquisa, sem professor com muitos preparos, uma vez que suas titulações poderiam até mesmo atrapalhar a exclusiva função de ensinar das faculdades municipais. Entre esses dois patamares de instituições há, ainda, mais uma divisão de águas: os "cursos fáceis" e os "cursos difíceis". Nos primeiros, inscrevem-se os das Ciências Humanas, e nos segundos, os das áreas das exatas, biológicas e as tecnologias.

Isso é o próprio reflexo dos ímpetos e espasmos da modernização operada na sociedade brasileira, cuja elite padece de um arcaísmo cultural, que a impede ver as 
Ciências Humanas num novo plano de saber, tanto humanístico, quanto epistemológico (MENDES, 1968, p. 35). Parece mesmo que os organizadores, incentivadores e professores da FFCL do município não teriam outra saída senão resignar-se com seu "menor papel", dedicando-se apenas ao ensino e à formação profissional, ainda mais se tratando de formação de professores de grau médio. Convém lembrar que as faculdades de licenciatura constituíam a maioria das municipais e é nelas que foi organizado o corpo docente de ensino superior, para a formação de professores do interior paulista.

A julgar pelo parecer do CEE-SSP, os títulos e atividades de ordem acadêmica dos currículos dos professores da FFCL de São José do Rio Pardo são desnecessários para formar professores de ensino médio.

\subsection{A Faculdade de Ciências Econômicas, Administrativas e Contáveis de Franca}

O debate sobre a profissão de economista e sobre a pesquisa econômica, no Brasil, mal se havia assentado na vida pública e nas universidades, quando foi criada a Faculdade de Ciências Econômicas de Franca (FACEF), mantida pelo Instituto Francano de Ensino (SAES e CYTRYNOWICS, 1999, p.16). Seu funcionamento foi autorizado pelo Decreto $n^{\circ}$ 29.377, de 20 de março de 1951, iniciando suas atividades sob a direção do professor Alfredo Palermo. É possível afirmar que essa foi uma das primeiras faculdades do interior do estado de São Paulo. Na inauguração, o diretor declarou seu propósito: "[solicito] aos presentes a máxima colaboração no sentido de transformar [...] o instituto de Ensino Superior em veículo de aprimoramento cultural de toda região" (FACEF, 1951).

É importante ressaltar que o professor Palermo permaneceu no cargo de diretor da FACEF por quase 13 anos, período de difícil assento da instituição como formadora de profissionais para a área de economia. Devido a sua liderança política e intelectual, não se limitou às ações junto a essa faculdade. Antes mesmo de sua fundação, já participara da criação do Instituto Francano de Ensino, em 1948, e, depois, participou da fundação da Faculdade de Direito, em 1957, onde atuou com diretor, entre os anos de 1959 a 1978. Por fim, participou da criação do Instituto Isolado de Educação Superior, de 1963, sob a dependência administrativa do Estado (SILVA, 2004, p. 32-34). Alfredo Palermo destacou-se como um dos grandes educadores de sua região e está para o ensino superior de Franca assim como a indústria calçadista está para a economia da cidade.

Valendo-se de sua experiência, o diretor dedica-se à busca de modelos de ensino em outras faculdades, pretendendo substância teórica e prática para as atividades docentes. Desse modo, encontram-se, na ata da sessão de inauguração, as primeiras ações do dirigente:

Iniciando o trabalho, o Diretor afirmou que obtivera programas para as diversas disciplinas, em faculdades congêneres de Belo Horizonte e São Paulo, podendo assim ter os professores uma orientação segura sobre desenvolvimento dos estudos na Escola (FACEF, 1951).

O modelo de ensino foi preocupação inicial, pois, como os debates teóricos na área das Ciências Econômicas ainda eram recentes no Brasil, tornava-se necessário procurar centros em que o ensino das disciplinas do curso tivesse alguma tradição. Fica evidente, enfim, que a constituição da faculdade padecia de planejamento e de quadros qualificados, para afirmar-se como instituição de ensino superior e poder, de fato, cumprir os propósitos proclamados em sua inauguração.

A FACEF não surge como instituição municipal e pública, mas privada e assim se mantém até a década seguinte. Nos primeiros anos de suas atividades, o diretor, professor 
Alfredo Palermo, elege um conselho técnico administrativo, para assessorá-lo nas questões administrativas e pedagógicas da faculdade. Em 1957, enfrenta-se a falta de candidatos para o curso de Ciência Econômica. Para o referido conselho, isso se devia a seu nãoreconhecimento, o que afastava os possíveis candidatos. O caminho proposto pelo conselho era a mobilização político-administrativa para a conquista do reconhecimento. Todavia, para verem concretizadas suas aspirações, diretor, conselheiros, professores, funcionários e alunos precisaram esperar por mais três anos.

No início da década de 1950, Franca projetava-se através de sua rápida expansão industrial no setor calçadista, promovida por uma nova classe de empreendedores, o que não requeria apenas o poder econômico, mas, também, político, ideológico e cultural, pois se enfrentava a antiga hegemonia dos fazendeiros de café (op. cit., 2004, p.29). Essa expansão significou o surgimento de outros postos de trabalho, configurando-se, paulatinamente, uma economia típica do capitalismo industrial, o que exigia, evidentemente, profissionais qualificados de nível superior.

No entanto, pelo menos para a recente faculdade, os fatos não se desencadearam de forma tão ordenada e consequente. Em 1955, realiza-se a primeira formatura de bacharéis em Ciência Econômica, sem que o reconhecimento do curso se tivesse efetivado. Os dirigentes da faculdade continuam articulando-se com pessoas de influência na instância de política educacional, para avançar no processo de reconhecimento. Em 1958, o então diretor, Alfredo Palermo, torna-se Deputado Estadual e empenha-se, pessoalmente, junto ao presidente da Câmara de Ensino Superior do Conselho Nacional de Educação (CNE), para acelerar o processo. Em seguida, foi contatado o então ministro Horácio Lafer para que, junto ao diretor da Câmara de Ensino Superior, professor Jurandir Lodi, apressasse o processo de reconhecimento da faculdade. Mediante o Decreto ${ }^{\circ} .48 .908$, de 27 de agosto de 1960, formalizou-se o reconhecimento do curso de Ciência Econômica de Franca.

Outra situação que a faculdade enfrentava era o recrutamento de professores para suas disciplinas. Através da pesquisa em atas do Conselho Técnico Administrativo, foi possível perceber que essa questão se resolvia com a contratação de profissionais ligados ao comércio, ao magistério médio, à advocacia e à engenharia. Assim narra o diretor da faculdade:

O conselheiro José Infante Vieira sugeriu os nomes dos senhores economistas Orlando Nicolau, Nicanor Xavier da Cunha e Everton Merlino, como assistentes e substitutos eventuais nas respectivas cadeiras: Valor Econômico de Preços, Estatística, Metodologia e Economia, Estrutura e Análise de Balanço e Contabilidade Geral.

O conselheiro Geraldo Alves, que é orientador educacional do Instituto Francano de Ensino, [...] sugeriu o nome do Sr. Luís Paulo Sinelli, que soube ser professor competente conhecedor da matéria [Matemática Financeira], uma vez que cursara até o $3^{\circ}$ ano da Politécnica, na Faculdade de Engenharia Mackenzie. O Sr. Alfredo Henrique Costa, com a palavra, disse que viria para Franca, o advogado Sr. Fred Nassif e que o mesmo, além de haver lecionado em Escolas Normais de São Paulo, havia feito o curso de "Sociologia Política". E que o mesmo manifestara o desejo de lecionar alguma cadeira na FACEF.

Vê-se, então, o modo com que foi organizando o corpo docente da Faculdade de Ciências Econômicas de Franca e, consequentemente, o processo de ensino e de formação de profissionais para a área. As urgências e os improvisos não são características que se inauguram com a fundação dessa faculdade, pois, nos estudos de Vieira (1979-1981, p. 
371), sobre a história da Ciência Econômica no Brasil, é observado que, até meados do século passado, não havia nem o reconhecimento legal da profissão de economista e, de modo geral, mesmo nas universidades, confundia-se teoria econômica com Contabilidade. Segundo o autor, foi em 1946, com a instalação da Faculdade de Economia, Administração e Contabilidade, da Universidade de São Paulo, e, dois anos antes, na cidade do Rio de Janeiro, com a criação da Fundação Getúlio Vargas, que foi possível sistematizar elementos do pensamento econômico internacional e nacional, para realizarem-se pesquisas sobre os fenômenos econômicos do país. Pode-se deduzir que, sendo a Faculdade de Ciências Econômicas de Franca quase contemporânea desses dois grandes centros de pesquisa, ela dificilmente conseguiria atrair catedráticos, pesquisadores e, mesmo, estudantes, uma vez que era apenas uma desconhecida faculdade do interior paulista, que, supunha-se, mal tinha ciência do que se formulava em termos de Ciência Econômica no país.

Os professores, todavia, eram conhecedores das questões críticas de seus campos acadêmico-profissionais e reclamavam por avanços. Em ata do Conselho Departamental, datada de 16 de outubro de 1953, o professor Jorge Cheade15 faz a seguinte observação:

Se faz necessário uma campanha junto aos órgãos legislativos federais, no sentido de encaminhar uma proposição capaz de precisar, sem subterfúgios, os direitos e deveres dos economistas, a fim de que a profissão possa ter, como as demais, os atrativos e garantias sociais necessários a seu pleno desenvolvimento.

O status social do economista não era reconhecido pela sociedade brasileira e, por isso, sua função não havia conquistado espaço no mercado de trabalho, nem mesmo na área científica. Apenas alguns nomes nos grandes centros produziam trabalhos acadêmicos e ocupavam importantes cargos na vida pública do país (SAES e CYTRYNOWICS, 2004; VIEIRA, 1979 -1981).

Após a reunião do Conselho Técnico e Administrativo de primeiro de março de 1958, somente em 1965 ocorreu outra, ou seja, houve um período de sete anos sem reuniões para tratar dos encaminhamentos da faculdade ou, pelo menos, sem registro de eventos dessa natureza. Porém, antes de 1965, através da Lei Municipal $\mathrm{n}^{\circ} 1.143$, de 9 de outubro de 1963, o Instituto Francano de Ensino perde sua condição de entidade mantenedora da Faculdade de Ciências Econômicas de Franca, assumindo-a a municipalidade. Assim, como unidade isolada de ensino superior, destinada a ministrar ensino das Ciências Econômicas, passa a funcionar como autarquia municipal ${ }^{16}$. A situação jurídica e administrativa da faculdade fica definida deste modo: Faculdade de Ciências Econômicas de Franca, autorizada a funcionar pelo Decreto Federal $n^{\circ} 29.377$, de 20 de março de 1951, reconhecida pelo Decreto Federal n ${ }^{\circ} 48.908$, de 27 de agosto de 1960, e encampada pela Prefeitura Municipal através da Lei Municipal n ${ }^{\circ} 1.143 / 63$.

Esse novo status jurídico requereu uma reorganização da faculdade e de seu corpo docente, a começar por seu regimento interno, que sofreu modificações promovidas pelo Conselho Técnico e Administrativo. Nas atas do Conselho Departamental do período estão as estratégias de trabalho adotadas para a elaboração do regimento, apesar de não se ter encontrado qualquer cópia de seu texto, provisório ou final. Em relação às estratégias, foi possível perceber uma ação concentrada no Conselho Técnico e Administrativo, não se constatando, contudo, se o debate se estendeu a todo o corpo docente.

Surgem, então, as primeiras atas dos departamentos do curso, a saber, Departamento de Matemática e Estatística, de Ciências Sociais, de Administração e Jurídico e de 
Contabilidade. A concomitância das datas das reuniões de todos os departamentos (junho de 1972) devia-se ao fato de que os professores se viram obrigados a obter os registros que os autorizavam a continuar ministrando suas disciplinas. Tais registros, deste então, passavam a ser concedido pelo CEE-SP, visto que, em decorrência de sua encampação municipal, a faculdade de Franca ficava sob a égide do referido conselho.

As reuniões dos departamentos, segundo suas atas, tratavam, somente, das indicações de professores para as disciplinas. Seus currículos e documentos comprobatórios deveriam ser acompanhados por pareceres de dois relatores, normalmente seus colegas de departamento. Sempre favoráveis, esses pareceres eram mais recheados de comentários elogiosos do que, propriamente, de análises e avaliações dos currículos, das titulações e das produções acadêmicas ${ }^{17}$. Um exemplo é o seguinte trecho:

Assim, tendo apresentado pelo professor Roberto Maurício Ginofre toda documentação exigida, designava como relatores os professores João Roberto Correa e Geraldo Alves Taveira [...] O referido professor [Roberto Maurício Ginofre] vem lecionando nesta escola as disciplinas de História do Pensamento Econômico com proficiência, desde 1969. É formado nos seguintes cursos em nível superior: Direito Administrativo (Público e Privado) e, presentemente, está cursando Pedagogia e Estudos Sociais. As disciplinas que o professor leciona já foram por ele estudadas, nos currículos de cursos superiores mencionados. Apresenta extensa folha de serviço prestado ao magistério. Farto é o material que apresenta correspondente aos trabalhos de pesquisas que realizou; assim, estão no processo apostilas e outras publicações sobre matéria econômica de autoria econômica [sic]. É pessoa de reconhecida capacidade cultural, em toda cidade [sic], sendo continuamente solicitado para palestras, conferências e opinião sobre problemas jurídicos e econômicos [...] Por isso, sou pela indicação para lecionar, pelo Departamento, as disciplinas de História Econômica Geral e História do Pensamento Econômico como Titular.

Aqui, é possível pensar a respeito das exigências para a formação do magistério de ensino superior, que atendia as faculdades municipais. Observa-se, no trecho citado, que a formação básica do professor não tem relação com as disciplinas para as quais foi indicado. Nem mesmo suas graduações posteriores correspondem a suas atividades docentes.

Essa situação, aliada às então recentes e incipientes formulações teóricoprofissionais no campo da Ciência Econômica, vai, como um quebra-cabeça, desenhando um quadro com nuanças de improviso, ajustado às condições locais e apoiado pelas ações dos órgãos federais e estaduais de educação. No III Seminário Sobre Assuntos Universitários, promovido pelo Departamento de Assuntos Universitários (DAU), do CFE, em 1968, Durmeval Trigueiro Mendes (1968, p.40) assim alerta seus pares: “[...] poucos se dão ao trabalho de procurar saber se a instituição, que começa mal com nossa complacência, não poderia começar bem, com a nossa ajuda".

Nesse sentido, a expansão de ensino, nas áreas denominadas Ciências Humanas, dizia respeito mais à ampliação quantitativa de vagas do que a um projeto de crescimento planejado do ensino superior. A relação da Ciência com as práticas sociais tomava a dimensão de regras normativas e, consequentemente, enquanto alguns centros do ensino superior as produziam, outros as repetiam. Esta fórmula, aliada ao caráter político da expansão do ensino superior das décadas de 1960-1970, possibilitou que, até mesmo, a 
prática de ensino fosse mal instalada, comprometendo a formação de seus alunos.

Uma década após a encampação municipal e apenas alguns anos após a reforma universitária de 1968, a FACEF passa por nova reformulação de seu regimento interno, prevendo-se a criação de um Instituto de Pesquisas Econômicas (IPES) como uma autarquia da Prefeitura, mas vinculado à faculdade.

A propósito de análise, é possível traçar alguns paralelos entre o IPES de Franca e as fundações de pesquisa de índices e fenômenos econômicos que surgiram, tanto no campo universitário como em setores do poder público e do empresarial. Só para citar alguns, tem-se a criação do centro de pesquisa da Fundação Getúlio Vargas (Rio de Janeiro), em 1944, e o Instituto Mauá, criado, em 1951, pela Confederação Nacional da Indústria do Rio de Janeiro. Em São Paulo, as entidades que fomentaram a pesquisa de mercado foram a Federação do Comércio e a Associação Comercial de São Paulo, que instalaram o Instituto de Pesquisas Econômicas em 1944. Finalmente, em 1965, com apoio da Fundação Ford, surge o Instituto de Pesquisas Econômicas da Universidade de São Paulo (VIEIRA, 1979- 1981, p. 366 - 68).

Tais instituições tiveram por fim sistematizar dados conjunturais da economia, bem como traçar análises macroeconômicas, auxiliando, direta ou indiretamente, os setores públicos e empresariais. Seguindo esses moldes, origina-se o IPES de Franca como uma autarquia municipal, tendo como objetivos, segundo seu regimento, aprovado pelo Decreto Municipal n n $^{\circ} .923$, de 31 de maio de 1973:

\begin{abstract}
Art. $1^{\circ}$. [ ...]:
I - Prestar serviço de economia e administração, de pesquisa, programação e processo e processamento eletrônico de dados a entidades e órgãos de administração direta da União, dos Estados e dos Municípios, bem como, a entidades privadas e estrangeiras.

II - Promover cursos, palestras, seminários, reuniões, de modo a permitir um maior desenvolvimento dos setores técnicos e administrativos.

[...].

III - Diligenciar junto a órgãos públicos, quer sejam federais, estaduais e municipais, no sentido de melhorar os métodos de planejamento e administração técnica, desenvolvendo as possibilidades de aplicação de processamento de dados, pesquisas e estudos.

Art. $2^{\circ}$. O IPES tem por finalidade o desenvolvimento, em qualquer grau, da pesquisa e do estudo de assuntos na área econômica, e a prestação de serviços de natureza técnica e científica a entidades públicas e privadas, nacionais e estrangeiras, a título gratuito ou oneroso.
\end{abstract}

Presume-se que havia o entendimento de que o instituto contribuiria para aprimorar o ensino e promover a pesquisa na FACEF e, ao mesmo tempo, desempenharia uma função importante nas políticas públicas direcionadas à econômica regional. O IPES de Franca, já na época, contava com a participação de representantes de diferentes órgãos e entidades patronais e sindicais da cidade. Entre seus departamentos, destacava-se o de pesquisa, cujos cargos eram ocupados pelos professores da faculdade.

Entretanto, durante a investigação, foi encontrada apenas uma publicação sobre pesquisa econômica do instituto, "Contribuição estatística à indústria de calçados de Franca, (1973)", tratando-se "[...] de um estudo estatístico inicial a respeito de produção de calçados num dos maiores pólos do setor coureiro deste país", tal como se anuncia na apresentação. O que chama atenção é que esse estudo é publicado pela Faculdade Pestalozzi de Ciências, Educação e Tecnologia, e não, como era de se esperar, pela FACEF. Esse dado corrobora a idéia de que a faculdade de Franca não promoveu, entre 
seus quadros, o interesse pela pesquisa e pela formação acadêmica de seus professores e alunos.

O caso da faculdade em questão reflete, tendo-se em vista um contexto maior, a situação da profissionalização do economista e a do próprio desenvolvimento da Ciência Econômica no Brasil. Vieira (1979-1981, p. 370-371) assim define o quadro acadêmico e profissional das Ciências Econômicas: os pesquisadores se ocupam com preocupações imediatas de solucionar certas anomalias apresentadas pelo sistema econômico, os professores do curso de Economia, geralmente, sentem-se cada vez mais desalentados a se dedicar ao ensino, uma vez que há outras oportunidades nas empresas e, paradoxalmente, multiplicam-se a criação de faculdades de Ciências Econômicas Contábeis por todo o Brasil, ultrapassando a necessidade do mercado nacional, prejudicando o ensino e a pesquisa e frustrando os alunos egressos dessas faculdades:

Considerando-se o exposto sobre a FACEF, os docentes ficaram restritos a um sentido utilitário e imediato, o que permite concluir que as contribuições da Ciência e da tecnologia, em um país, região ou cidade, têm seus limites na orientação que a sociedade dá a seu próprio desenvolvimento.

\subsection{A Escola de Engenharia de Piracicaba}

Convém considerar os conceitos de técnica e de tecnologia desenvolvidos por Vargas (1994, p. 15-34), para melhor contextualizar a história da Escola de Engenharia de Piracicaba. Para o autor, o primeiro diz respeito à "habilidade humana de fabricar, construir e utilizar instrumentos. É tão antigo quanto a humanidade [...] em simultaneidade com a característica humana de utilizar símbolos capazes de correlacionar objetos com o pensamento e o instinto humano". Já a tecnologia, "só pode ter vigência depois do estabelecimento da Ciência moderna, principalmente pelo fato de essa cultura ser um saber que, apesar de teórico, deve necessariamente ser verificado pela experiência científica".

Piracicaba, segundo consta, enfrentou uma longa fase de estagnação e alguma decadência durante muitos anos do século XX, o que se acentuou na década de 1950, com a expansão acelerada de Campinas. Isso, apesar de ter sido uma das primeiras cidades do interior paulista a industrializar-se, não só em decorrência do crescimento da produção açucareira, mas também da instalação de algumas metalúrgicas e indústrias mecânicas, produzindo-se inclusive, equipamentos para usinas de açúcar. É a partir de década de 1970 que Piracicaba começa a vencer a estagnação econômica, com os investimentos infraestruturais, especialmente rodoviários, a criação de distritos industriais e o programa PróÁlcool.

O ensino de Engenharia em Piracicaba surgiu com a criação da Fundação Municipal de Ensino Superior de Piracicaba, através da Lei Municipal $\mathrm{n}^{\circ} 1.524$, de 5 de outubro de 1967, promulgada pelo então prefeito Luciano Guidotti. Como entidade de direito público, seu objetivo era instalar e administrar a Escola de Engenharia de Piracicaba (EEP) e, conjuntamente, a Escola Técnica Industrial.

Assim como ocorreu para as faculdades de Rio Pardo e a de Franca, a prefeitura de Piracicaba foi fundamental para a instalação da escola de Engenharia. Coube-lhe a subvenção orçamentária anual para a instituição, como, ainda, a doação de terreno e o estabelecimento de convênios com órgãos de outras instâncias governamentais. Foi um ato do poder local que nomeou o Conselho de Curadores da Fundação Municipal de Ensino Superior de Piracicaba ${ }^{18}$.

Um ano mais tarde, em 19 de fevereiro de 1968, é criada a Escola de Engenharia de Piracicaba com o curso de Engenharia Civil, iniciando-se suas atividades no ano seguinte. 
Seu reconhecimento se deu através do Parecer $n^{\circ}$ 2.038/72, do CEE-SP. Em seu primeiro estatuto, estavam previstos cursos de graduação e pós-graduação. Em seu Artigo $5^{\circ}$, alínea b, caberia ao último nível de ensino:

a) estimular o aperfeiçoamento do ensino e do pessoal docente e de pesquisa, contratando especialistas e orientadores de alto nível, concedendo bolsas de estudos, prêmios ou auxílios financeiros, fornecendo recursos para obras didáticas ou técnicas para a realização de pesquisa e trabalhos experimentais; b) instituir e manter, em Piracicaba, sob sua direção, institutos ou cursos de pós-graduação, programas, pesquisas e cursos de extensão e aperfeiçoamento.

$\mathrm{Na}$ origem da EEP, a pesquisa científica coloca-se como uma de suas atribuições, prevendo-se expressamente subvenções para essa atividade, sem as quais tudo não passaria de mero discurso. É desse modo que, no dia 07 de fevereiro de 1969, pela Resolução $\mathrm{n}^{\circ}$ 2/69, o Secretário de Estado dos Negócios de Educação autoriza o funcionamento da Escola de Engenharia de Piracicaba como autarquia municipal, oferecendo o curso de Engenharia Civil condicionado à exigência de manter o Colégio Técnico Municipal. No primeiro regimento interno da escola, seus objetivos estão assim definidos:

a. Formar engenheiros civis.

b. Incentivar e realizar pesquisas científicas e tecnológicas no interesse do ensino, da cultura do desenvolvimento do País.

c. Promover a formação de pessoal docente de nível universitário.

Não foi possível verificar se, desde o início das atividades da EEP, foram realizadas pesquisas, tais como estão preconizadas nesse registro. O que se pode afirmar é que os cursos de Engenharia, para serem aprovados pelos órgãos oficiais, precisam ter instalados laboratórios tecnológicos para atender ao ensino, já no primeiro ano de curso. Por outro lado, seus professores devem comprovar experiência profissional com uma titulação que os credencie a manipular o laboratório, que, por fim, tem mais sentido didático do que de pesquisa. São cursos cujas características científicas se revestem de empreendimento tecnológico. No caso da escola de Piracicaba, sua base social de sustentação passa por professores, engenheiros e, também, empresários da indústria pesada da cidade que, de um modo ou de outro, reconhecem a necessidade de pesquisa científica e tecnológica.

Através da leitura do regimento de 1969, foi possível observar a influência da Lei $\mathrm{n}^{\circ}$ 5.540/68 na organização interna da EEP. Na definição de departamento, por exemplo, transcreve-se o que estabelece a mencionada lei: “[...] como unidade didático-científicoadministrativa, constituída pela reunião de disciplinas afins e serviços auxiliares". Para o mesmo regimento, cada departamento deveria ser chefiado por um docente titular que "haja conquistado a docência-livre ou doutoramento". Desse modo, fica estipulado o plano de carreira, segundo o qual se classificam os professores da seguinte maneira:

a. Pessoal docente - professor-titular, professor-associado, professor-assistente e instrutor.

b. Professor-titular - Deveria apresentar título de docente-livre ou doutor, tese original e inédita, versando sobre assunto de livre escolha, relativo á disciplina do concurso - Poderá a Congregação, pelo voto de $2 / 3$ de seus membros em exercício, autorizar a inscrição do candidato que não possua título de livre-docente ou de doutor, desde que apresente atividade científica comprovada, relativamente à disciplina em concurso.

c. Docente livre - Destinar-se-ia a ampliar a capacidade do ensino e da pesquisa da Escola. A instituição da docência livre é obrigatória.

d. Professor-associado - Livre-Docente por concurso de títulos e provas e 
portador de título de Doutor realizado de acordo com os termos deste Regimento, passarão a exercer a função de professor associado.

e. Professor-assistente - Portador de diploma de título de mestre, obtido em instituição oficial ou reconhecida.

f. Instrutor - Docente portador de diploma de nível superior, devendo obter, dentro de seis anos, a contar da data do primeiro contrato, o título de mestre, sob pena de exoneração e perda irrevogável do contrato caso não o faça.

g. Professor-colaborador - Seria o docente estranho ao corpo docente da EEP, ou profissional de reconhecida competência, contratado por período transitório e determinado, que seja investido de função didática ou de pesquisa, por deliberação da Congregação, podendo ser brasileiro ou estrangeiro.

A EEP foi a única instituição, das pesquisadas, que previu em seu regimento um plano de carreira baseado em titulações acadêmicas. Se essa prerrogativa foi seguida rigorosamente, é o que se poderá verificar mais adiante, quando se apresentarão a constituição do corpo docente e os currículos atinentes. A princípio, presume-se que seus conselheiros se tenham servido de outros modelos institucionais para compor a organização interna da escola, baseados no caráter científico exigido pela Engenharia e pelo ensino de nível superior.

No regimento de 1969, estão definidas as possibilidades de convênios com centros técnicos e científicos, com o intuito de aprimorar o ensino, realizar pesquisa ou promover cursos de pós-graduação. Por isso, em 1972, é celebrado um convênio entre a EEP e a Escola Superior de Agricultura Luiz de Queiroz (ESALQ), para a utilização de equipamentos eletrônicos (computadores IBM), cuja autorização é reconhecida pelo reitor da USP que, por sua vez, autoriza os professores da ESALQ, que se dedicavam em regime de tempo integral, a lecionar nos cursos de Engenharia da faculdade municipal.

Nunca é demais lembrar que essa área técnico-científica é estratégica para o desenvolvimento da indústria e seus desdobramentos estão diretamente ligados aos interesses dos capitais estatais e privados. Por outro lado, o projeto científico da sociedade brasileira dos anos de 1960 ingressa na lógica instrumental do alto aporte tecnológico, regulamentado por leis de patentes e de absorção de "know-how" estrangeiro. Portanto, presume-se que a Escola de Engenharia de Piracicaba, inserida numa região industrializada $^{19}$, reflete esse contexto maior da Ciência e que seu processo de instalação e consolidação é mais metódico, por se tratar de Ciência aplicada à tecnologia, observandose, então, uma fragmentação do mundo científico, que se cinde em pesquisa básica e pesquisa aplicada.

Com isso, a organização que vai se desenhando nas escolas municipais de nível superior, como se vê neste estudo, se configura como um verdadeiro mosaico, em que se distingue a universidade do estabelecimento isolado, o curso "fácil" do curso "difícil" e a exigência de uma "organização científica" da exigência de apenas ensino normativo. Desse modo, as orientações das instâncias oficiais competentes diferenciaram-se nos procedimentos de autorização e de reconhecimento de cada curso ou faculdade.

O processo de implantação dos cursos de Engenharia Mecânica e de Elétrica é exemplar nesse sentido, uma vez que a autorização de seus funcionamentos foi muito criteriosa e recheada de pareceres de especialistas das áreas, o que evidencia diferenças de postura quanto à orientação oficial e à implantação das faculdades aqui tratadas.

Em 04 de julho de 1974, começa o processo de autorização para a EEP ministrar os cursos de Engenharia Mecânica, Elétrica e Operacional. Para isso, o diretor Sady Fidelis Previtalli encaminha um ofício para o CEE-SP, acompanhado por um parecer do Conselho de Curadores, da Fundação Municipal de Ensino de Piracicaba, em que ressalta, como 
justificativa, a existência de indústrias com aporte tecnológico para desenvolver "knowhow" e absorver mão-de-obra especializada.

Em resposta ao processo, o Conselheiro do Estado da Educação, Alpínolo Lopes Casali, descreve longamente as atribuições do CEE-SP, em relação às autorizações e reconhecimentos. Lembra o conselheiro o Decreto-Lei $n^{\circ} 464$, de 11 de fevereiro de 1969, que não autoriza o funcionamento de universidades e de estabelecimentos isolados de ensino superior, se não correspondem às exigências de mercado de trabalho. Essa hipótese, observa o conselheiro, não se aplica em situações em que a iniciativa apresente um alto padrão e seja capaz de contribuir, efetivamente, para o aperfeiçoamento do ensino e da pesquisa nos setores abrangidos. Sendo assim, o pedido é acolhido restritivamente, permitindo apenas a instalação do curso de Engenharia Mecânica e designando o Professor Dr. Rosalvo Tiago Rufino, "engenheiro e ilustre professor da Engenharia de São Carlos da USP", tal como consta no parecer, para fazer análise das condições da EEP para oferecer o curso.

No relatório do professor designado, entende-se que, para o curso de Engenharia Mecânica atender, plenamente, as exigências de ensino e pesquisa, deveriam montar os laboratórios de Química e Física, de computação básica e programação, de eletricidade, de fenômenos de intercâmbio, de materiais de construção mecânica, de sistemas térmicos, de sistemas de fluidos mecânicos e de tecnologia mecânica. O professor Dr. Rosalvo relata sobre as condições de cada laboratório existente e, para aqueles que ainda deveriam ser adquiridos, oferece sugestões sobre convênios e aquisições para instalá-los. Assim, prossegue em seu relatório:

A escola, pelo silêncio, aceitou como necessários os laboratórios [por ele indicado]. É interessante registrar que os laboratórios mencionados coincidem com os relacionados pelo professor Heitor Gurgulino de Souza, eminente membro do CFE, em recente Parecer, que se reestrutura o ensino de engenharia em âmbito nacional.

Seguem, abaixo, as sugestões referentes aos laboratórios que faltavam na Escola de Engenharia de Piracicaba:

Quanto ao laboratório de Computação Básica e Programação [sugiro] a celebração de um convênio com a ESALQ. Em relação aos demais laboratórios, indico a conjugação de esforços da Escola, Prefeitura Municipal e com o potencial das indústrias locais. [Deste modo], pede a autorização do curso com vista à aquisição dos laboratórios exigidos à formação do Engenheiro Mecânico.

A essa manifestação, a EEP respondeu de imediato, apresentando o convênio firmado com a ESALQ e o compromisso da Fundação Municipal de Ensino de Piracicaba para equipar os laboratórios existentes e implantar novos. Enfim, concluindo seu relatório, o professor Rosaldo Rufino apresenta parecer favorável ao "funcionamento do curso de Engenharia Mecânica na Escola de Piracicaba em virtude das características do município que se torna pólo da indústria mecânica principalmente".

Depois da verificação in loco das condições de oferta do curso, o conselheiro Alpínolo Lopes Casali defere o pedido de autorização, apontando os estudos sobre o ensino de Engenharia no Brasil, do professor Heitor Gurgulino de Souza, então diretor do Departamento de Assuntos Universitários (DAU). Ressalta o conselheiro do CEE-SP: 
Até o fim de 1972, existiam, no País 101 instituições dedicadas ao ensino de graduação em Engenharia. Delas 31 estavam instaladas no Estado de São Paulo, 14 no Estado de Minas Gerais, 8 no Estado do Rio Grande do Sul, 4 no Estado de Pernambuco, as demais pulverizadas no Brasil afora (ESCOLA DE ENGENHARIA DE PIRACICABA, 1972, p. 3).

Por conseguinte, procurava-se demonstrar que ainda era necessário formar engenheiros para o país e, como Piracicaba era um pólo de concentração industrial, estavam dados os "elementos [que] concorrem favoravelmente para a autorização imediata de instalação do curso de Engenharia Mecânica" (op.cit., 1972).

O exposto não deixa dúvida de que o processo de implantação de um curso na área tecnológica era mais criterioso e detalhado do que os de cursos das áreas não-tecnológicas. Isso, pode-se argumentar, é devido ao equipamento técnico sofisticado que exigem os primeiros, mas se presume que não se trata apenas disso. A autorização e reconhecimento de qualquer curso e de qualquer área deveriam seguir critérios rigorosos, respaldados em pareceres de especialistas reconhecidos pela comunidade técnico-científica. O que parece mais certo afirmar é que, numa sociedade de regime liberal como a brasileira, a expansão de ensino superior deveria ser planejada, tendo-se em vista as vontades subjetivas da população jovem e as possibilidades objetivas da oferta de cursos qualitativamente constituídos. Sem isso, assistem-se esforços regrados para os cursos considerados nobres e, para os não-nobres, a massificação do ensino e a desobrigação da unificar ensino e pesquisa.

Convém examinar, ainda, a segunda parte do processo de autorização do curso de Engenharia Mecânica da escola de Piracicaba, o que corrobora a idéia sobre o rigor de sua implantação. Depois do relatório do especialista sobre a necessidade de laboratórios, segue o parecer do Conselheiro Alpínolo Lopes Casali, nos seguintes termos:

O relator adotou como suas as prescrições do professor Rosalvo Tiago Rufino, a respeito da montagem ou da complementação dos laboratórios necessários aos $3^{\circ}, 4^{\circ}$ e $5^{\circ}$ anos. Quanto aos do $1^{\circ}$ e $2^{\circ}$ anos, a Escola já os possuía; seriam comuns aos dois cursos de Engenharia (SÃO PAULO, 1972, p.1).

É ponto pacífico que o CEE-SP tinha a atribuição de produzir normas para as universidades e estabelecimentos de ensino superior sob sua jurisdição, cabendo-lhe autorizar ou não o funcionamento dos cursos dessas instituições. No entanto, o processo em análise foi sui generis, pois foi encaminhado ao Departamento de Assuntos Universitários (DAU), a fim de conhecer as posições e as recomendações de seus especialistas, que comentam a aprovação do CEE-SP que se deu em 19 de dezembro de 1975.

Nos termos daquele Parecer, entretanto, não se configura plenamente a pretendida autorização, pois que o funcionamento do $3^{\circ}, 4^{\circ}$ e $5^{\circ}$ séries deverá ser precedido da sujeição ao Conselho Estadual de Educação, do corpo docente, do plano currículos e equipamentos dos laboratórios que se tornarem necessários. Assim sendo, dada a inexeqüibilidade de um decreto autorizativo parcial ou condicional, esta preliminar exige a devolução do processo às suas fontes para a devida reconsideração.

O CEE-SP acata a apreciação do DAU, mas também considera as condições favoráveis ao funcionamento do curso, tais como: mercado de trabalho, população da cidade, parque industrial, posicionamento geográfico e acesso às faculdades públicas de 
Engenharia. Por tudo isso, permite o funcionamento dos dois primeiros anos, sob a condição de a prefeitura e a Fundação Municipal de Ensino de Piracicaba comprometeremse a instalar novos laboratórios e a sofisticar os equipamentos dos já existentes, conforme as necessidades da formação do engenheiro mecânico. As exigências foram cumpridas e aprovadas pelo CEE-SP e, também, pelo CFE, através do Decreto ${ }^{\circ} 83.755$, de 23 de julho de 1979.

Isso posto, pode-se afirmar que a Escola de Engenharia de Piracicaba, apesar de seus esforços, não possuía condição para desenvolver conhecimento tecnológico a partir da Ciência básica, mas é possível inferir que ela desenvolveu atividades de pesquisas aplicadas à indústria, devido às especializações de seus professores.

\title{
Considerações finais
}

Estão, assim, traçadas as origens históricas de cada faculdade municipal, tendo em vista as singularidades, os perfis e a constituição das escolas superiores do interior de São Paulo. Nas longas e cautelosas construções jurídicas e sociais do caleidoscópio do ensino superior, a sociedade assiste a um redimensionamento das relações entre universidade e cultura e a um novo desenho das estruturas institucionais, que as conforma às configurações do racionalismo científico. Isso se evidencia em escala mundial e o sistema educacional brasileiro não foge à regra. Por conseguinte, é fundamental ter a noção de que...

\begin{abstract}
Os sistemas de educação superior massificados tendem a desempenhar uma pluralidade de papéis frequentemente contraditórios, uma característica que se acentua ainda mais em uma sociedade tão profundamente estratificada e diferenciada como a brasileira. Parece ser mais recomendável reconhecer as diferenças, e tratar de responder a elas de forma pluralista, do que tratar de negá-las pela via de imposição de igualdades formais, que tendem a intensificar ainda mais os processos de estratificação e de desigualdade (ARAUJO \& SCHWARTZMAN, 2000, p.9).
\end{abstract}

Todavia, é necessário ponderar de forma crítica sobre essa ideia, pois não se trata de responder às novas exigências do mercado que dilui tudo, que tudo transfere de um lado para o outro e produz a obsolescência rápida da mão de obra e o desemprego estrutural. Trata-se, antes de qualquer coisa, de desenvolver a imaginação educacional e recuperar o núcleo fundamental do ensino superior, que é a formação. Para isso, é importante localizar as faculdades municipais no conjunto das relações do sistema de ensino superior brasileiro.

Ocorre que as histórias dessas faculdades, embora se substanciem em fatos particulares e isolados, se inserem em processos que, de modo muito significativo, guardam relações com a própria evolução do ensino superior brasileiro. Seu caráter de faculdades isoladas não é algo inaugural nesse nível de ensino. A oferta de cursos para as "novas profissões", que contam com pouca ou nenhuma tradição acadêmico-intelectual, não está justificada por uma necessidade regional, mas, antes, por uma transformação da função do ensino superior, frente às exigências das novas formas do capitalismo pósindustrial. A lacuna existente na produção científica não é privilégio desse setor institucional, mas uma inconsistência presente, até mesmo, em algumas universidades brasileiras. As facilidades para a expansão do ensino superior não estão registradas apenas no período ditatorial-militar, quando se deu a fundação da maioria das faculdades municipais, pois deitam raízes nas primeiras décadas da República (CUNHA,1986, p.163). 
Portanto, a história das faculdades municipais do estado de São Paulo, espelhando o contexto maior em que se insere, é complexa e densa. Ao estudá-las, desvendam-se elementos importantes para a compreensão da própria educação brasileira. Sendo assim, outra não pode ser a tarefa, senão a de refletir sobre as condições e formas com que se constituíram, para cumprirem seus papéis institucionais na educação formal. Nesses termos, é válido apontar elementos de sua constituição histórica para, assim, vislumbrar outras chances de estudo deste setor de ensino superior.

Como componentes de uma estrutura institucional complexa, que se organizam em relação ao conhecimento científico, as faculdades municipais têm ocupado uma parte significativa da formação de jovens que completam a última etapa de sua escolaridade, especialmente no que tange a formação de professores. Em conformidade aos traços acadêmicos trilhados, cabe-lhes, portanto, defender publicamente o aperfeiçoamento de seu ensino e de sua possível inserção no campo da pesquisa, no sentido de democratizá-los entre alunos e professores, optando pela firme recusa à apropriação privada do conhecimento.

Suas próprias histórias de sobrevivência em quase meio século e o aperfeiçoamento de seus professores tornam indispensável a conquista, se não de uma autonomia didáticocientífica, o que exige processos acadêmicos e jurídicos muito complexos, pelo menos de uma cultura de ensino superior mais efetiva, em que se redimensione o tempo de trabalho do corpo docente e do discente. Sem isso, qualquer tentativa de aprimoramento é como "jogar gotas de água em chapa quente". Fala-se, no caso, de uma cultura em que o didatismo típico nas instituições acadêmicas de hoje dê lugar ao estímulo do espírito científico, aquele que se substancia na curiosidade e na investigação rigorosa, como processo válido de um aprendizado, em que a mera assimilação do conhecimento dê lugar à sua produção.

A formação de qualquer profissional deve introduzi-lo no passado de sua própria cultura e da que ele adquire na faculdade, para que possa pensá-las em termos de presente, priorizando as condições sociais relacionáveis a sua área de conhecimento. A aludida cultura de ensino superior deve pautar a formação dos estudantes em uma ampla base formal, cultural e política, norteadora de uma relação de responsabilidades com sua profissão, sua área de conhecimento e com a sociedade em geral.

As faculdades necessitam ampliar significativamente suas capacidades e competências para o atendimento educacional de estudantes que sejam oriundos da educação média precária e daqueles com idades mais avançadas, através de novos instrumentos pedagógicos, da implantação sistemática de diferentes modalidades de cursos e da oferta de alternativas educacionais, ajustadas a suas aspirações e potencialidades. Além do mais, os professores, ao dirigirem-se aos alunos inseridos na dinâmica curricular, devem considerar as condições "históricas de cada disciplina, o conhecimento de seus estudos clássicos, as questões que lhes deram nascimento e as transformações dessas mesmas questões" (CHAUÍ, 2003, p. 8).

Caberia, ainda, às faculdades municipais, estabelecer uma relação dinâmica com a comunidade em que emergiram, em dois importantes aspectos: (a) o de garantir a representação da comunidade em suas instâncias decisórias e (b) o de constituir uma equipe multidisciplinar de pesquisa para estudar fenômenos locais, a partir de análises abrangentes. Estas são algumas considerações possíveis a partir das histórias constitutivas das faculdades municipais paulistas que, uma vez colocadas, tem a expectativa de estimular novos estudos sobre este objeto da educação superior. 


\section{Referências}

ARAUJO \& SCHWARTZMAN, Relação centro-pereferia: o caso da autonomia universitária. Disponível em htpp://WWW.10minutos.com.br/Simon/centroper.htm> Acessado em 27/05/2000.

BRETAS, S.A. A rede municipal de ensino superior do estado de São Paulo: Novas questões sobre velhos problemas. Araraquara, 2005, 194f. (Doutorado em Educaáo Escolar) - Faculdade de Ciências e Letras/UNESP/Car.

CASPARD, P. L'état et individu en historie de l'éducation: problèmes de sources et de méthode. In: SEMINÁRIO HISTÓRIA DA EDUCAÇÃO BRASILEIRA: A ótica dos pesquisadores, 1994, Belo Horizonte. Anais... Brasília: INEP, 1995 (Série Documental: Eventos, n. 6).

CHAUÍ, M. A universidade pública sob nova perspectiva. In $26^{\mathrm{a}}$ Reunião Anual da ANPEd. Poços de Caldas. Novo governo, novas políticas? O papel da ANPEd na produção das políticas educacionais. Associação Nacional de Pós-Graduação em Educaçao, 2003, p. $17-21$.

CUNHA, A universidade temporã. Da Colônia à era Vargas. $2^{\mathrm{a}}$ Ed., Francisco Alves: RJ, 1986.

DIAS, F. C. Construção do sistema universitário no Brasil: memória histórica do Conselho de Reitores das Universidades Brasileiras. Brasília: CRUB, 1989.

ESCOLA DE ENGENHARIA DE PIRACICABA. Ofício 303, de 18 de novembro de 1972. Sobre exigência de relator do Conselho Estadual de Educação de São Paulo, Processo $n^{o}$ 1283/72, referente ao reconhecimento da Escola de Engenharia de Piracicaba.

Prontuários do corpo docente. Arquivos inativos de 1964 a 1978.

GUERRA. R. Faculdade: 30 anos. Gazeta do Rio Pardo, São José do Rio Pardo, cad. Especial, 25 mai. 1996.

MACHADO NETO, A. J. Globalização e gestão universitária: um estudo das instituições municipais de ensino superior do estado de São Paulo. 2000. Dissertação (Mestrado em Administração de Empresas) - Faculdade de Ciências Econômicas e Administrativas de Franca (FACEF), Franca.

MENDES, D. T. A expansão do ensino superior no Brasil. Revista Documenta, Brasília, n. 91, p. 26-66, set. 1968.

REVISTA DOCUMENTA. Brasília: Ministério da Educação e Cultura; Conselho Federal da Educação, jan. 1968 a set. 1968 (nº 80 a 91).

REVISTA LOGOS, v. 1, n. 1. São José do Rio Pardo: Faculdade de Filosofia Ciências e Letras de São José do Rio Pardo, jun. 1969.

SAES, F. A.; CYTRYNOWICZ, R. O pensamento econômico e as origens da profissão de economista no Brasil (1931-1945). In: CONGRESSO BRASILEIRO DE HISTÓRIA ECONÔMICA, 3, 1999. Curitiba.

SÃO PAUlO. CONSELHO ESTADUAL DE EDUCAÇÃO. Deliberação $n^{\circ}$ 406/68. Aprova normas regimentais provisórias da Escola de Engenharia de Piracicaba (Diário Oficial do Estado de São Paulo n. 247, 28 dez. 1972. 
Ensino Superior Municipal de São Paulo. São Paulo, CEE, 1995.

(SÃO PAUO, 1995, p. 11)

SÃO JOSÉ DO RIO PARDO. Lei Municipal $n^{\circ} 415$, de 27 de abril de 1964. Cria a Faculdade de Filosofia, Ciências e Letras de São José do Rio Pardo.

Prontuários do corpo docente. Arquivos inativos de 1964 a 1978.

TEIXEIRA, A. Estudo especial: Interpretação do Art. 15 da LDB/61. In REVISTA DOCUMENTA. Brasília: Ministério da Educação e Cultura; Conselho Federal da Educação, n 81 , jan. a set. 1968.

VAIDERGORN, J. As seis irmãs: as faculdades de Filosofia, Ciências e Letras - Institutos isolados de ensino superior do estado de São Paulo, 1957-1964: alguns subsídios interpretativos para o estudo do ensino superior do estado de São Paulo. 1995. Tese (Doutorado em Educação) - Universidade Estadual de Campinas, Campinas.

VARGAS, M. (org.). História da técnica e da tecnologia no Brasil. São Paulo: UNESP/Centro Estadual de Educação Tecnológica Paula Souza, 1994.

VIEIRA, D. T. A história da Ciência Econômica no Brasil. In: FERRI, M. G.; MOTOYAMA, S. História das Ciências no Brasil, 3. São Paulo EDUSP, 1979-1981, p. 347-372.

WARDE, M. J. Contribuição da História para a educação. Em Aberto, Brasília, ano 9, n. 47, jul./set. 1990.

Notas

${ }^{1}$ Doutora em Educação Escolar pelo Programa de Pós-Graduação em Educação Escolar - Faculdade de Ciências e Letras - UNESP/CAr. Atualmente é Professora Adjunta do Departamento de Educação da Universidade Federal de Sergipe - UFS. - e-mail:s-bretas@uol.com.br

Universidade Federal de Sergipe - UFS

2 Autarquias, sociedades de economia mistas e empresas públicas. As fundações de direito público ou privado foram incluídas na administração indireta a partir da Lei 7.597/87.

${ }^{3}$ Ressalta Dias (1989) que, a partir de 1975, o ritmo de expansão diminuiu sensivelmente, voltando a crescer na década de 1980, surgindo onze IMES novas, para desacelerar-se, novamente, nos anos de 1990.

${ }^{4}$ Esse dado se manteve até a publicação do CEE-SP (1999, p.132), muito embora haja mudança na organização institucional, como, por exemplo, os institutos isolados, que ampliaram seus cursos, que formaram um conjunto de faculdades de diferentes áreas do conhecimento, transformando-se em centros universitários.

5 Em 1992, a maior concentração de IMES estava no estado de São Paulo (uma universidade e 40 estabelecimentos isolados), seguido por Santa Catarina (três universidades, três federações de faculdades integradas e três estabelecimentos isolados), Pernambuco (11 estabelecimentos isolados), Goiás (10 estabelecimentos isolados), Paraná (sete estabelecimentos isolados), Minas Gerais (cinco estabelecimentos isolados), Espírito Santo (três estabelecimentos isolados). Rio de Janeiro (um estabelecimento isolado) e Tocantins (um estabelecimento isolado) Cf. Bretas, 2005.

${ }^{6}$ Cabe registrar os nomes dos que participaram de tal comissão: Professor Vinício Rocha dos Santos, Dr. Osvaldo Galotti e Dr. Antonio Ferraz Monteiro.

${ }^{7}$ Ibidem, idem. Destaques nossos.

${ }^{8}$ Processo no $358 / 69$, p. 2, CEE-SP. 


\footnotetext{
${ }^{9}$ Não encontramos relatórios dos anos subseqüentes.

${ }^{10}$ Editado pela Casa Euclides da Cunha, sob o patrocínio da Secretaria de Cultura, Esporte e Turismo do Estado de São Paulo, em 1969.

${ }^{11}$ Publicado com o apoio da Secretaria de Ciência e Tecnologia do Estado de São Paulo.

${ }^{12}$ Grifos nossos

${ }^{13}$ Destaques nossos.

${ }^{14}$ Fixa normas de organização e funcionamento do ensino superior e sua articulação com a escola média, e dá outras providências.

${ }^{15}$ Que, em 1963, seria o novo diretor da FACEF.

${ }^{16} \mathrm{O}$ diretor, Professor Alfredo Machado Neto, revela que o processo de encampação da faculdade contou com a participação dos cidadãos francanos que, através de campanha da prefeitura, adquiriram bônus municipais como forma de contribuir financeiramente para a mudança de mantenedora. Para esse estudo, foram procurados, além dos materiais disponíveis nos arquivos inativos da faculdade, outros documentos que informassem sobre este fato. As buscas estenderam-se ao arquivo da Câmara Municipal de Franca e seus funcionários nos informaram que não havia documentos a este respeito, indicando o Museu Municipal, onde, também, não foram encontrados os documentos que registrassem a participação dos munícipes no processo de encampação da Faculdade de Ciências Econômicas de Franca.
}

${ }^{17} \mathrm{Na}$ FACEF não foram investigados os prontuários de professores, pois, no arquivo a que tivemos acesso, não foi encontrado este tipo de documento.

${ }^{18}$ Foram nomeados conselheiros: professor Dr. Admar Cervelino, professor Archimedes Dutra, Dr. Artur Affonso de Toledo Almeida, professor Manuel Carlos Muller de Araújo, engenheiro agrônomo Dovílio Olmeto, professor Dr. Eurípedes Malavolta, engenheiro e arquiteto João Chaddad, professor Joaquim do Marco, comerciante Lino Morganti, Grande Oficial Mário Dedini, Dr. Manuel Gomes Tróia e professor Dr. Rubens Souza Carvalho. Os títulos e as profissões estão textualmente transcritos. Não é possível afirmar que o título de doutor antes do nome corresponde a uma titulação acadêmica ou ao status social que goza aquele que se gradua em Engenharia e torna-se reconhecido, pela sociedade, como doutor. O título "Grande Oficial”, decerto, de alguma loja maçônica local.

${ }^{19}$ Na década de 1970, já estavam instaladas em Piracicaba a Usina Dedini, a Indústria Belgo Mineira, a Caterpillar e a Philips.

Recebido em julho-2012

Aprovado em novembro-2012 